\title{
VIRAL HEPATITIS
}

\author{
W. Paul Havens, Jr., M.D. \\ Departments of Microbiology and Medicine, The Fefferson Medical College of Philadelphia, \\ Philadelphia, Pennsylvania
}

INSIGHT in the importance of viral hepatitis is furnished by the degree to which it has occupied the time of numerous workers throughout the world. Attesting to this during the past decade are approximately 2,600 papers, published in 23 languages. About one-third of these are in English. A review of a representative segment of the work done during the past 20 years reveals that while many have been attracted to the field, only a small number of faithful followers have survived. Lavish at times and at others parsimonious have been the rewards of their efforts. Impetuous claims have been followed by the slow, erosive denials of time, and more than one eager devotee has been crushed by the failure of his colleagues to repeat his reported success. After two decades the often-cited major problems are as crucial now as they were in 1942 , i.e. (a) the failure to propagate human hepatitis viruses in any host except man and $(b)$ the consequent lack of a specific serologic test for their identification. Over the years many claims of successful transmission of human hepatitis viruses to a variety of laboratory animals, embryonated eggs, and cultures of cells of various species were made but not corroborated by others. However, recent reports of the isolation of strains of viruses from patients with hepatitis in cultures of human cells have again stimulated new hope and the outcome of these interesting studies is eagerly awaited, although it is easy to appreciate that the long dismal record of unrequited claims tends to be discouraging.

The real rewards throughout the years have come from studies in volunteers, and ever since the initial successful transmission of infectious hepatitis in Germany (Voegt, 1942) and serum hepatitis in the United States (Oliphant, Gilliam and Larson, 1943) there has been a progression of investigations that have resulted in an imposing mass of information. During World War II and

\footnotetext{
Some of the investigations on which this report is based and in which the author participated were carried out under the sponsorship of the Commission on Viral Infections of the Armed Forces Epidemiological Board, and were supported by the Office of The Surgeon General, Department of the Army.
}

for a short time thereafter, studies with voluntee were carried on in the Middle East, England and the United States. All of this work and the clinical and epidemiologic observations the available were reviewed by Havens (1948, 1954a.9. During the past eight years, further studies wi serum hepatitis and infectious hepatitis have been highly productive. It is the purpose of this pape्్ to pick up the threads of the information presentef in the review of 1954 (Havens 1954a), relating what has happened since that time to certain facts or concepts that had been previously eluct dated.

\section{INFECTIOUS HEPATITIS Virus A}

Because of the high incidence of infectigis hepatitis among children in the Willowbrofe State School in New York and its importanc해용 a cause of loss of time among nursing personin when they contracted the disease, Dr. Robe Ward and Dr. Saul Krugman were invited by thes school authorities to assist them in epidemiolog studies and control of the disease. As a result of the investigations subsequently carried ouf important information, either new or supples menting previously known facts, became available Early studies in volunteers had revealed virem three days before the onset of disease, during the preicteric phase, and in the early icteric phase of disease (Havens, 1948). These findings we corroborated (Ward, Krugman, Giles, Jacobs and Bodansky, 1958) and it was also shown tha viremia was present 25 days after experiment\& infection and 2-3 weeks before the appearance of jaundice, although attempts to recover virus from the blood a week earlier ( 8 days after experio mental inoculation) were unsuccessful (Krugman, Ward, Giles, Bodansky and Jacobs, 1959). Th duration of viremia has been a matter of intere 85 and concern from the beginning of the studies 0 hepatitis, and the work at Willowbrook corrobos ated in part studies made in the 1940's when number of unsuccessful attempts were made to recover virus at intervals from $\mathrm{I}-\mathrm{I} 3$ months aftep the onset of disease (Havens, I948). Because of this, the concept had developed and appears 
still valid that the average patient could be regarded as no longer infectious as far as blood was concerned one month after the onset of disease, although it was indeed suspected early that this was probably not true for all patients. That this doubt was justified was proved by the demonstration of Virus A in the blood of a patient, completely recovered, eight months after the onset of infectious hepatitis (Murray, Diefenbach, Geller, Leone and Ratner, I955).

Similar temporal relationships have been found to characterize the duration of presence of Virus A in the fæces. That it was present in the stools of patients during the acute phase of disease was demonstrated independently and almost simultaneously in England (MacCallum and Bradley) and in the United States (Havens, Ward, Drill and Paul) in 1944. This has been repeated in other studies, including those done at Willowbrook during recent years. Here, also, it was shown that virus may be excreted in the fæces 25 days after experimental inoculation (when viremia, as stated above, was also present) and two to three weeks before the appearance of jaundice. However an attempt to recover virus from fæces obtained two weeks earlier (eleven days after experimental inoculation) was unsuccessful (Ward and Krugman 196r). Just as the duration of viremia was, from the beginning, a matter of interest, so was the duration of persistence of virus in the fæces. The early attempts in the 1940's failed to recover virus from the fæces of adult patients one, three, and eleven months after the onset of illness, and similar attempts among children at Willowbrook one month after onset were also unsuccessful. Because of the results of the early studies, it was generally believed that patients were no longer infectious as far as the fæces were concerned one month after onset, although again, as with viremia, it was suspected that this need not always be true. The detection of virus in the stools of two infants with chronic hepatitis five and fifteen months, respectively, after the onset of their disease justified this suspicion (Capps, Bennett and Stokes, 1950). The evidence that has accumulated over the past two decades supports the concept that the infectivity of blood and fæces occupies a period of at least three to four weeks in the incubation period and acute phase of disease in a large percentage of patients. That viremia or fæcal excretion of virus may continue for prolonged periods under certain circumstances is also quite clear, supporting the concept long appreciated on epidemiologic grounds that the carrier is an important medium for the maintenance and transmission of infection.

The possibility of more subtle relationships between virus and host, though long suspected, was not placed on a firm footing until the detection of viremia by Krugman and his associates (1959) in a subject 37 days after experimental inoculation when the subject was clinically well and without any evidence of hepatic dysfunction except for a mild increase in serum glutamic oxalacetic transaminase. Thus, it would appear that viremia may exist in asymptomatic persons for a considerable period of the incubation period when tests of hepatic function are normal and also at a time appropriate for the onset of disease when the only evidence of hepatic involvement is a minor abnormality of one test of hepatic function. The frequency of occurrence of such an apparently benign relationship is unknown, although it is quite likely that it is far more common, particularly among children, than previously suspected.

In the course of innumerable attempts to isolate hepatitis virus from man, a number of known human viruses, including strains of ECHO and adenoviruses (unpublished), Coxsackie virus (Morris, Elisberg, Pond and Webb, 1962), and herpes simplex viruses, as well as a number of enzootic viruses (Morris and Nakamura, 1959), have been recovered but regarded as commensals unrelated to hepatitis. The long history of failures (or successes that were eventually regarded as failures because of inability of others to reproduce them) was reviewed in 1954 (Havens, $1954 \mathrm{~b})$ in relation to the many attempts to propagate hepatitis Virus $A$ in a wide variety of laboratory animals and birds, embryonated eggs, and cultures of various human and animal tissues. Since then, similar failures and successes have been reported from many widely separated places in the world; however, a review of the supporting evidence for the alleged success reveals nothing that is convincing (Havens, I963).

The new wave of enthusiasm engendered recently in the United States by reports of the isolation of several strains of viruses from patients with hepatitis by American workers is based on claims of success in cultures of $(a)$ monkey kidney tissue (McKee, I962); (b) human embryonic lung tissue (Davis, I96I); (c) chimpanzee kidney cells (Hillis, I96I); and $(d)$ human cells (Chang, 196I). The last mentioned is an interesting immunologically nonreactive virus called lipovirus. Whether any one of these strains of virus will eventually be shown to have a causative role in human hepatitis remains to be seen, and much more needs to be done before this information becomes available.

The most prominent candidate strains of hepatitis-associated viruses as far as the publicity they have received are the strains first described by Rightsel, Keltsch, Tekushan and McLean (1956). They were isolated on cultures of human 
cells and, as might be expected, provoked tremendous interest. Although the efforts of a number of other laboratories to reproduce these initial results were unsuccessful, the original investigators can only be complimented on their persistence, and in the past two years they have modified certain cumbersome aspects of their techniques and have again described success. Three strains of virus were allegedly propagated on cultures of similar cells and, in addition, the inoculation of tissue culture material into volunteers produced hepatitis after an incubation period of 30 to 42 days (Taylor, Rightsel, Boggs and McLean, 1962). The serologic evidence adduced to support the causative role of these viruses in the disease sustained by the volunteers is less than orthodox; however, certain of their physical properties are indeed compatible with what is known about hepatitis viruses, i.e. (a) relative stability when exposed to heat and ether, and $(b)$ size of about $15 \mathrm{~m} \mu$ in diameter as defined by electron microscopy and ultrafiltration. Again, it can only be hoped that these results will be reproduced in other laboratories; however, this may not be as simple as might be desired since the techniques used still present problems and the likelihood of further difficulties with them is good.

Many years ago, Essen and Lembke (r944) described polyhedral particles with a diameter of the order of $180 \mathrm{~m} \mu$ when visualized by electron microscopy in duodenal secretions of patients with hepatitis. Since then a number of studies have been made and enthusiastic reports have come from Austria (Braunsteiner, Fellinger, Pakesch, Beyreder, Grabner and Neumayr, 1957), the United States (Gueft, 196r), and Nigeria (Bearcroft, 1962). Particles of variable size, some of them compatible with what is suspected of hepatitis Virus A, have been described occurring as dense cytoplasmic inclusions with a dark central granule in duodenal secretions and hepatic cells. Whether these actually represent hepatitis virus is, as yet, unknown.

\section{Epidemiology}

Infectious hepatitis has emerged as a common disease of the mid-part of the twentieth century, and in $195^{2}$ cognizance was taken of its importance as well as that of serum hepatitis in a meeting of the World Health Organization at Liége, Belgium. During recent years, the incidence of infectious hepatitis has increased in both hemispheres in northern and southern latitudes. Among the several similarities that exist between this disease and poliomyelitis, McCollum (1962) included the evolution of their epidemiologic patterns, both diseases having emerged into a phase of longterm widespread epidemicity after obscure begin- nings with brief periods of localized outbreaks. 迎 Hungary and Czechoslovakia where reporting ofs compulsory, hepatitis has reached pandemic proportions, and in Australia and Denmark the rates have been high. In contrast are the relativedy low rates reported for Greece and Italy, raising the question that the available figures mily represent less than accurate notification in the areas (McCollum, 1962). In the United Stat where viral hepatitis was not generally notified until 1952, early records of the incidence of infectious hepatitis were better kept in Californo than in most places, and the major increase there occurred during the past decade (Clark, Beck, Edwards and Drake, 1960). The same appears have been true throughout the country, and tw 8 large outbreaks occurred in 1954 and 1961 . present, the morbidity is declining in the Unite States, completing a cycle of seven years that rather like the six to ten year cycles common seen in other countries. Mortality has not fluctup ated significantly in the United States, and the occurrence of $55^{\circ}$ to 900 deaths per year during the past eleven years provided a constancy that was in contrast to the variability in morbidity during this period. One possible explanation this situation was provided by Dauer (196r) who attributed the former to deaths from segiff hepatitis, while infectious hepatitis providedghe sharp fluctuations in morbidity. Of integest in this regard is the experience in Denmark we two severe outbreaks with high mortality occurre in 1933 and 1943. Since the latter, the highly fatal form of hepatitis has practically disappeareg and there has been a fairly steady decline it morbidity to a level of 31.6 per 100,000 pey annum in 1961 , the lowest figure ever recorded in Denmark. However, this is considerably highe than the maximum incidence notified in the United States in the same year, and the question. can be asked again whether the reporting in the latter country has, as yet, attained maximum. effectiveness. The notification of infectious hepatitis has been highly irregular in variou角 parts of the world, ranging from the extremes of none to the enviable records of Denmark and Sweden where accurate statistics are availab concerning morbidity and mortality since 19280 From such records and from the descriptions of localized outbreaks in areas where reporting is less well done has sprung a tremendous amount dot information. While much of this has come frone civilian sources, the high incidence of disease among the military of many nations during the past two decades has also furnished valuable knowledge and indeed has been a stimulus too closer study of the disease among civilians. MuclP of this was reviewed in 1954 (Havens), and since् 
then outbreaks among the military and civilians have continued to provide experience that corroborated and, at times, extended previously available knowledge.

The concept that the most important way of transmission of disease is by direct contact appears still to hold, although several interesting accounts of common-source outbreaks continue to appear. A huge water-borne epidemic due to fæcal contamination of a river was described in India (Melnick, I957) as well as other small outbreaks in the United States due to fæcal contamination of streams (Mosley, 1959), wells (Poskanzer and Beadenkopf, 1961), and municipal water supplies that had been inadequately precipitated before chlorination (Wilcox, Davenport, Coohan, Papsdorf and Johnson, 196r). Food was also implicated, and the personnel of certain ships of the Sixth Fleet, U.S. Navy, were involved in an outbreak while based in the Mediterranean Sea (McCollum, I96I). Contaminated food bought from family vendors on the docks in Naples was regarded as the likely source of infection. A fascinating tale of epidemiologic detective work was spun by Mason and McLean (I962) who discovered raw oysters as the source of one outbreak in the United States, and Dougherty and Altman (1962) similarly incriminated raw clams in another. In both instances, the shellfish were obtained from fæcally contaminated water; however, their role would doubtless not have been suspected if the investigating epidemiologists had not been struck by the unusually high incidence of disease among adults, particularly adult males. The suspicion that an unusual situation might be involved directed attention to the possibility of a common source of infection. It serves to point up the importance of increasing marine activities in small boats as well as the overloading of sanitary facilities at water resorts as sources of pollution of water harboring shellfish.

Epidemiologic evidence has long emphasized the probable importance of the carrier as a medium for maintenance of virus and its transmission. How frequently the carrier state persists for prolonged periods and whether it exists as an intermittent or constant phenomenon in the individual carrier is not known. The recent experiments of Krugman and his associates (1959) have added to previously known data concerning the duration of viremia and excretion of virus in the fæces so that now it is appreciated that these phenomena may exist for at least three to four weeks in infected persons, regardless of whether there is any evidence of clinical disease. The fact that virus was present in the frees (and the blood) of asymptomatic experimentally infected subjects I 8 days after inoculation and two to three weeks before the onset of jaundice confirms the long held suspicions that such a situation doubtless existed and was important in the spread of disease.

Of particular interest in this regard was the recent report of an outbreak of hepatitis among handlers of chimpanzees newly arrived in the United States from Africa (Hillis, 1961). Following this, the Communicable Disease Center, in Atlanta, Georgia, began the collection of other data, and, to date, 73 human cases of a disease clinically indistinguishable from infectious. hepatitis have occurred in persons having close contact with chimpanzees, monkeys or gorillas three to six weeks before the onset of illness (CDC Report No. 13, 1962). The majority were chimpanzee-associated, although this cannot be interpreted as any unusual susceptibility of the chimpanzee to infection or the carrier state. The significance of these observations awaits definition; however, it would seem likely that the route of infection was man to subhuman primate to man, with infection occurring in the subhuman primate shortly after arriving in this country or, indeed, in Africa in the period following trapping and awaiting shipment. Without developing clinically recognizable hepatitis, these animals apparently excreted virus for variable periods in the fæces, making infection of the handlers possible.

\section{Clinical Course of Disease}

The descriptions of clinically apparent hepatitis that came out of the experience of World War II have not been supplemented in any significant way during the past few years since the last review in 1954 (Havens, 1954a) with the exception of the interesting report of an outbreak of cholestatic hepatitis among U.S. soldiers (Dubin, Sullivan, Legolvan and Murphy, I960). Ward, Krugman and Giles (1960) in their studies included clinical descriptions of a mild disease in children from which complete recovery was the rule. Whether the second attacks that occurred in approximately $5 \%$ of their cases represented the effect of inadequate immunologic response or the impact of another strain of virus is not known. It is doubtless pertinent to point out that the incubation period of 34-50 days that they described in their experimentally transmitted disease is actually not particularly different from the shorter incubation periods of $16-42$ days described by others years ago for experimentally transmitted infectious hepatitis (Havens, 1948). The former incubation periods were calculated from inoculation to day of appearance of jaundice, while the latter were calculated from inoculation to the first appearance of symptoms that usually occur 7-10 days before clinical jaundice is evident. 
Although the ratio of inapparent to clinically diagnosed infections has long been thought to be variable but high, Ward and Krugman (196r) stressed the frequency of inapparent infections in children and suggested that the ratio might be as high as twelve to one. Their role epidemiologically was emphasized, and interest in it led to studies that resulted in a new insight into the natural history of the disease. The discovery of hepatitis Virus $A$ in the blood and fæces of children in the incubation period of experimentally transmitted hepatitis two to three weeks before recognition of jaundice, when there was no evidence of clinical disease or hepatic dysfunction, provided the necessary data to establish the fact that an alimentary phase, long recognized on epidemiologic, clinical, and pathologic grounds, is an integral part of the natural history of disease. This plus the fact that viremia was found in an asymptomatic subject 37 days after the ingestion of Virus A, when the diagnosis of infectious hepatitis was made solely on the basis of a slight increase in serum glutamic oxalacetic transaminase, urged the acceptance of a wide spectrum of severity of infection with Virus A. The question could well be asked whether infectious hepatitis is indeed a good name for this disease, since the spectrum might range from $(a)$ an asymptomatic alimentary form without demonstrable hepatic damage, to $(b)$ asymptomatic infection with minimal hepatic dysfunction, to $(c)$ clinical hepatitis, with or without jaundice (Havens, 1962). Only the development of specific virologic and immunologic techniques can establish the validity of this concept.

\section{Sequelæ}

As a result of certain experiences in World War II among U.S. troops in the Mediterranean Theater (Barker, Capps and Allen, 1945), a great fear of chronic hepatitis developed among physicians and laity, particularly in the United States, even though there was at no time sufficient evidence to prove that it actually was an important hazard. During the past decade the situation has been viewed more realistically by some, (Martini, 196r) but there are others who have taken the opposite extreme. For the latter, the persistence for several months of mild hepatic dysfunction, with or without clinical evidence of disease, is the only acceptable residual of acute hepatitis, and cirrhosis of the liver apparently has no place in the natural history of this disease. The genesis of this belief lies in the failure to find evidence of significant residual hepatic disease in groups of U.S. (Zieve, Hill, Nesbitt and Zieve, r953) (Neefe, Gambescia, Kurtz, Smith, Beebe, Jablon, Reinhold and Williams, 1955) (Chalmers, 196r) and
British veterans (Cullinan, King and Rivers, I958 several years after they had acquired epidemac hepatitis or serum hepatitis. The lack of a histo of preceding hepatitis in a considerable percentage of patients who came to clinical awareness onty when they established chronic liver disease $\vec{s}$ cited in support of this concept. However competent observers in England (Sherlock, 194\%, the United States (Ratnoff and Patek, 1955), and Germany (Kalk and Wildhirt, 1960) have describ $\overline{\overline{a d}^{d}}$ chronic progressive hepatitis and cirrhosis following a disease that is clinically indistifpguishable from acute viral hepatitis and, indee $\bar{\Phi}$, the increase in mortality from chronic livet disease in Denmark during the past 15 years regarded as an aftermath of the great epidemic of infectious hepatitis in the mid-r940's (Bjornebog, 1957). In addition, the frequency of undiagnosed infections makes it impossible to say that chron hepatic disease is unrelated to preceding infectiong

In spite of interest in inadequate diet insufficient rest, intercurrent infections, and oth $\overrightarrow{\mathrm{Ab}}$ nonspecific factors as possible conditioning influences in the development of chronic hepatitis, the two major unanswered questions are whethex it is due to $(a)$ the persistent activity of virus $\underline{T}$. (b) some inherent defect in the host. There is ng reason to believe that the nonspecific factorsages operative, and there is no practical way to detetmine whether hepatitis virus persists in patiê.ts with chronic hepatitis, although it has beee demonstrated to do so on occasion. Howeve, whether it is implicated in the production chronic disease under this circumstance unknown, since it has also been found in perfect $\frac{\vec{\Phi}}{\bar{\phi}}$ healthy persons.

In an effort to explain the development chronic hepatic disease, Gear (1946) suggested that it might be the result of autoimmune mechan isms. He postulated that any noxious materia承. including chemicals, bacterial toxins, or viruses might function as the initiating injurious force subsequently combining with products of cellula destruction that in certain patients evoked a antibody, which in its union with antigen provokee further cellular injury, thereby establishing self-perpetuating progressive disease. This was: not seized upon at once with enthusiasm, althougf it is of interest that a good bit of nonspecific serologic evidence accumulated before and aftę Gear's initial suggestion lent some support to $\mathrm{ft}^{\mathrm{D}}$ (Havens 1948, 1954b). However, in the past few years a great deal of interest has been manifeste? in this idea, particularly in Australia and the United States. Mackay, Taft and Cowling (1956) in Australia coined the term 'lupoid hepatitis and since then a number of papers recentlo reviewed by Mackay (196I) have appeared frorg 
both continents. The results of earlier serologic studies were extended and materials were found in the serums of patients with chronic hepatitis that bound nuclear and cytoplasmic substances (Deicher, Holman and Kunkel, I960) (Paronetto, Schaffiner and Popper, 196r). Fluorescence microscopy was employed to demonstrate gamma globulin in the livers of patients with chronic hepatitis (Cohen, Ohta, Singer and Popper, 1960). Although the concept is attractive and, indeed, it is quite clear that chronic hepatitis may flourish in a biologic environment that contains many of the phenomena associated with auto-immune disease, the final proof is not yet available that auto-immune mechanisms produce chronic hepatic disease in man (Havens, 1959). Most of those concerned with the possibility that it might be true believe that cellular rather than circulating antibodies are important in continuing the damage. Since the latter are generally regarded, however, as reflecting the presence of cells that might be involved in production of cellular antibody, the report of Good and Page (I960) of the occurrence of acute yellow atrophy and postnecrotic scarring of the liver, respectively, in two patients with agammaglobulinemia who contracted acute hepatitis casts some doubt on the importance of auto-immune mechanisms in their evolution.

\section{Laboratory Studies}

The numerous attempts to devise serologic tests for the diagnosis of viral hepatitis resulted in the description of a series of nonspecific reactions that have been interesting in many instances but of little value except possibly for a recently developed hemagglutination test. Many of these were reviewed (Havens, I954b), but since then a number of others have been described, including the use of $(a)$ suspensions of Bacillus prodigiosus treated with acute-phase serums for agglutination tests (Infectious Hepatitis Report, 1960), and (b) the Schultz-Dale reaction in guinea pigs to detect soluble antigens in serum (Makari, 1960). Two sorts of crude neutralization tests were also described, utilizing convalescent-phase serums to neutralize the inflammatory effects of injecting acute-phase serum into $(a)$ the allantoic fluid of embryonated hens' eggs (Pollard and Diserens, I $95^{6}$ ), and $(b)$ the anterior chamber of the rabbit's eye (Infectious Hepatitis Report, 1960). Although claims of specificity were made, others were unsuccessful in reproducing them.

Over the years, hope has repeatedly been engendered that some sort of tests employing hemagglutination might be as valuable in viral hepatitis as it has in infectious mononucleosis. Despite the detection of agglutinins for the erythrocytes of a number of species including man in a small but variable percentage of sera of patients with acute hepatitis, neither specificity nor value could be ascribed to them. The description of hemagglutinins for day-old chick erythrocytes in acute-phase serums of monkeys with yellow fever suggested the possibility that they might also be found in acute-phase sera of patients with viral hepatitis. This was indeed found to be true in $70 \%$ of patients (Morris, 1957) (Havens, 1958, I960) (McCollum, Bech, Isacson and Riordan, 1959). The hemagglutinins appeared early, frequently before the onset of disease, and disappeared after two to three weeks. That they were intimately related to the acquisition of hepatitis was well demonstrated; however, there appeared to be no specificity to the reaction as far as hepatitis virus was concerned. Of importance is the fact that the test is uniformly negative in patients with obstructive and hemolytic jaundice, lending it value in differential diagnosis (Havens, 1962).

Descriptions of numerous metabolic and biochemical changes occurring during the course of hepatitis have been reviewed or noted elsewhere (Iber and Mendeloff, 1962)(Havens, 1963). Among the most important was the measurement of certain serum enzymes and, from the diagnostic and prognostic standpoints, the measurement of the serum glutamic oxalacetic transaminase has doubtless achieved the greatest use (Wróblewski, Jervis and LaDue, 1956). It is of particular diagnostic value in hepatitis without jaundice or in the preicteric phase of disease and later when there may be difficulty in differentiating obstructive jaundice. During convalescence, it serves as. a guide to prognosis (Bodansky, Schwartz, Krugman, Giles and Jacobs, 1960).

\section{Treatment}

The treatment of viral hepatitis is concerned with the provision of rest and a well-balanced diet. Over the years, certain extremes in management have evolved only to reverse themselves to a more realistic position in the middle of the road. The nonspecific and supportive nature of the measures available has been reviewed recently (Iber and Mendeloff, 1962), summing up the situation quite adequately. Attention has been called to the fear of development of chronic hepatitis that plagued both medical profession and laity during the I940's and earty I950's and the naturally resulting prolonged hospitalization or confinement to bed that in some areas attained the ridiculous (Havens, 1962). Indeed it was rebellion against this that prompted a study in U.S. occupation troops in Germany (Swift, Gardner, Moore, Streitfeld and Havens, 1950) and subsequently in U.S. troops in Japan (Chalmers, 
Reynolds, Eckhardt, Cigarroa, Deane, Reifenstein, Smith and Davidson, 1955). The observations made indicated what many already knew but were reluctant to express, that patients convalescent from hepatitis could tolerate more activity than generally believed and, more concretely, that patients allowed up in their rooms or ward following a period of one hour's rest after each meal did just as well as those kept strictly at rest in bed. Actually, by such gradually increasing activity, they were able to return to duty one week sooner.

Dietary regimens went through similar excesses, and the sharp reduction in fats, for no justified reason, resulted frequently in large, unattractive amounts of carbohydrate and protein being offered to patients whose appetites were at best not vigorous. The recommendation of a well-balanced diet containing 2,000-3,000 calories, with $19 \%$ in protein, roo-120g. of fat, and the remainder in carbohydrate, was welcomed by most (Chalmers and associates, 1955).

The question when a patient is ready to return to active life has been the subject of numerous discussions. A realistic approach appears to be that this is possible when the serum bilirubin measures less than $1.5 \mathrm{mg}$., Iooml, the bromsulphalein retention $10 \%$ or less $(5 \mathrm{mg}$. $/ \mathrm{kg}$. body weight, 45 minutes), the patient is asymptomatic, and the liver no longer tender.

In the absence of specific treatment, it is no wonder that the use of adrenal steroids should have occupied the efforts of many. Although favorable changes following their administration have been widely described and reviewed (Iber and Mendeloff, 1962), their use has been recommended for only seriously sick patients or for those with prolonged illness. The use of these materials has doubtless been wider among patients with cholangiolitic hepatitis or chronic hepatitis, and the benefits that have been observed in some of these patients, particularly among the former group, have caused the recommendation of a trial of therapy in all such patients (Sherlock, 1958) (Havens, 1962). In patients with cholangiolitic hepatitis, itching has been relieved by the use of a resin sequestering bile salts in the intestinal tract (Havens, r 963). Attention must be paid to the level of prothrombin in the blood since it may be sharply reduced during treatment, requiring the use of vitamin' $\mathrm{K}$ parenterally.

\section{Prevention}

The prolonged duration of viremia and excretion of virus in the fæces makes it difficult to prevent the spread of infectious hepatitis, particularly when a large percentage, as among children, never develop clinically recognized disease. In those in whom the diagnosis is made, it has been recommended that the stools be regarded cas infectious for at least four weeks, and adequ承e sterilization of instruments coming in contact wh the blood of such patients has been re-emphasized. Normal human gamma globulin, previou淢y thought to prevent infection, has more recenfly been shown to modify it. Krugman and Wagd (1961-1962) found the incidence of nonicte infection as great in children who had receives gamma globulin. The amounts used have ranged widely, and from $0.0 \mathrm{I}-0.06 \mathrm{ml}$./lb. of botely weight, intramuscularly, have been effectie. Amounts of $0.01-0.02$ have frequently been reported as effective in children, although Krugman and Ward (196I-1962) have questioned whether this might be enough in adults. Off particular importance in answering this questiog is the presumed amount of exposure that the adult might encounter. Thus, larger doses mightit be recommended for persons going to live in areas where the disease is highly endemic $a \overrightarrow{\mathrm{B}} d$ where control of hygienic facilities, particulady food-handlers, might be less than desirable. Under such circumstances, repeated adminstration of gamma globulin at stated intervals might פe considered. The duration of partial protection 80 derived depends on the dosage and has Been estimated to range from four to eight weeks. If exposture is heavy, however, it has been shorgion children that protection persists for many mon (Ward and Krugman, 196r), and this has been regarded as strong support for the concept thet under such conditions partial passive protection might be supplemented by active immunity. Tlarat this might also occur for adults living under conditions of high exposure would justify the repeated adminstration of gamma globulin to the

\section{SERUM HEPATITIS}

The importance of serum hepatitis today emerges as a civilian problem and stems large्dy from its mortality. Although the over-all death rate from this form of hepatitis in previousty healthy young adult males, as experienced in the great epidemic following the administration off yellow fever vaccine to U.S. troops in 1941-19 was low and similar to that of the epidenotic disease in similar groups $(<2 / 1000)$, Parr (1945) pointed out that differences in incubation perisid and possibly severity of disease were related 90 differences in fitness of the host. This was borre out by the increased mortality in wounded men who acquired hepatitis from transfusions $\bar{B}_{\mathrm{f}}$ plasma or blood; and subsequently in civilian life the mortality of hepatitis so acquired by olfer and debilitated persons, who were most likely \$oreceive transfusions, has been a matter of gre⿻彐丨冖巾 
concern. That variations in strains of virus might be partially operative in conditioning these differences has also been suspected. Unfortunately, the diagnosis of serum hepatitis must be made on the basis of a preceding history of circumstances allowing the parenteral transmission of virus, although in occasional situations of common-source infection the epidemiologic background has been of crucial assistance. Without more specific measures, the true incidence of the disease cannot be defined. The sharp diminution in the use of plasma in certain parts of the world during the past fifteen years has greatly reduced common-source outbreaks attributable to it, although they still occur on occasion (CDC Report No. 12, 1962). Serum hepatitis exists now as a clinical entity largely on the basis of infections transmitted by transfusions of whole blood and by inadequately sterilized instruments. Varying estimates have been made of the carrier rates of hepatitis viruses among adults, depending on the time and place of survey. A recent estimate of Stokes (1962) in the United States placed the figure at 2 to $4 \%$. Among recipients of whole blood, the risk of serum hepatitis has also been reported as highly variable, ranging from 0.3 to $4.13 \%$. Of interest and importance has been the suggestion that professional donors carry a greater hazard (Allen, Dawson, Sayman, Humphreys, Benham and Havens, 1959). The role of inadequately sterilized instruments doubtless is far more important in transmitting disease than is generally suspected. Attention has been drawn to this possibility in certain areas where parenteral therapy is common in general practice, and the frequently described outbreaks of jaundice in clinics and their cessation following appropriate sterilization of instruments are a matter of medical history (Havens, 1948, 1954a). That individual physicians might be implicated in such situations was reported in 1948 (Correspondence-Naples) following the occurrence of an outbreak among the practice of a physician in Italy, and more recently outbreaks were ascribed to the use of inadequately sterilized equipment in the offices of two physicians in the United States (Dull, I96I) (CDC Report No. I2, 1962). In this regard, attention was called again to the possibilities of infection in certain dental procedures (Knighton, 196r).

\section{Hepatitis Virus B}

Early studies in experimentally infected volunteers, reviewed elsewhere (Havens, 1948, 1954a), revealed viremia to be present in the acute phase of disease and during the prolonged incubation period 87 days before the onset of disease, 60 days before the appearance of jaundice, and 16 days before the appearance of jaundice.
Similar attempts to recover virus from the blood during convalescence from one to five months after onset were unsuccessful (Havens, 1948). Subsequent studies (Stokes, Berk, Malamut, Drake, Barondess, Bashe, Wolman, Farquhar, Bevan, Drummond, Maycock, Capps and Bennett, 1954) (Neefe, Norris, Reinhold, Mitchell and Howell, 1954) (Murray, Diefenbach, Ratner, Leone and Oliphant, 1954) were designed to furnish evidence of the carrier state that was already well accepted on clinical and epidemiologic grounds. As a result of these studies, it was shown that certain persons with or without hepatic disease might remain carriers for as long as five years. In addition, Virus B was found in the blood of a donor I35 days after he gave a transfusion that was believed to have produced hepatitis in the recipient. The same donor subsequently developed hepatitis and was again proven to have viremia six months after recovery (Murray and associates, 1954).

As in infectious hepatitis, claims have been made over the years of successful transmission of Virus B to a variety of laboratory animals, embryonated eggs, and cultures of tissues of a variety of species. These have been reviewed previously (Havens, 1948, 1954b) and attention has been called to the failure to substantiate any of these claims. More recently, reports were made of the isolation of hepatitis Virus $B$ on cultures of embryonic human lung (Bolin, Alsever, Barger and Jarvis, I96I) and on cultures of a variety of cells by O'Malley, Meyer and Smadel (196r). The former experiments have not been reproduced by others; the latter are of particular interest since the virus isolated was obtained from a pool of plasma known to contain hepatitis Virus B, and patients convalescent from serum hepatitis were found to have neutralizing antibodies against this agent. The results of further studies are awaited with interest.

As in infectious hepatitis, attempts have been made to visualize hepatitis Virus B by means of electron microscopy. During recent years, reports have come from Austria (Braunsteiner and associates, 1957) and the United States (Gueft, 196I) describing oval cytoplasmic particles $400 \mathrm{x}$ $600 \AA$ in size in sections of the liver from patients with serum hepatitis. Again, as with Virus A in infectious hepatitis, there is inadequate evidence to prove that they actually represent hepatitis Virus B.

\section{Epidemiology}

It has long been suspected that the epidemiology of serum hepatitis and infectious hepatitis has interrelationships, although they have never been defined. From the clinical standpoint, the 
coexistence of these two diseases became apparent with the first known outbreak of serum hepatitis described by Lürman (1885). Since then, numerous descriptions of the occurrence of both diseases in the same geographic areas have been recorded. This subject was reviewed in 1957 (Havens), and it was emphasized that strains of Virus A and Virus B had been shown to coexist in several parts of the world. For example, during World War II, strains of Virus B were found in the Middle East and Italy during epidemics of infectious hepatitis and in the United States and England where infectious hepatitis was endemic and of low incidence. In the period of Occupation of Germany when infectious hepatitis was apparently widespread, a strain of Virus B was also found (Evans, 1950). The differences and similarities between them are familiar to all, and the former, in particular, have been the subject of speculation. It has been suggested that the prolonged incubation period of serum hepatitis is a function of the route of inoculation, yet the demonstration years ago that Virus A fed orally or injected parenterally produced hepatitis with similar short incubation periods negates this concept. The fact that Virus A is excreted in the fæces following parenteral inoculation (Havens, 1946) has always appeared to be in striking contrast to the failures to recover Virus B from the fæces of patients with serum hepatitis. That there may be occasional exceptions to the latter, however, has been hinted by the rare occurrence of hepatitis in the wives of soldiers with serum hepatitis and the description of contact cases in one outbreak of serum hepatitis reported by Mirick and Shank (1959). Attention was called recently (Havens, I96I-I962) to the possibility that Virus B need not depend on the needle for its survival but rather on the emergence of new strains derived from Virus A that had undergone alterations in certain properites during prolonged residence in the host with alimentary disease and viremia. Thus, biologic survival might be guaranteed despite the fact that alterations in properties would make transmission dependent on parenteral inoculation. Whether such speculations may be removed from the realm of fantasy and given a solid basis of fact depends on the development of specific immunologic techniques. Without them, we can also do little more than think in terms of two strains of hepatitis viruses, $A$ and $B$, although the history of multiple attacks of hepatitis in persons at high risk of parenteral infection such as narcotic addicts (Havens, I956) has suggested that several strains may exist. Stokes (1962) has recen re-emphasized this possibility, citing in suppert of it the apparent differences in modifying effe of normal human gamma globulin.

\section{Prevention}

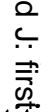

The inability to detect the presence of hepatitis virus in human blood or its products and the lesk of practical effective means to rid most of them $\overline{\bar{\omega}}$ of viable virus remain the major problems in prevention of parenterally transmitted diseasse. At present, human albumin and gamma globưfin prepared by ethanol fractionation are the of components know to be free of the danger $\vec{f}$ f transmitting hepatitis. The attempts to utilize్g a number of so-called hepatic functional studises, with special emphasis on those reflecting alterationss in serum proteins (Alsever, Barger, Priest ajd Love, 1961) and enzymes (Bang, Ruegseggefr, Ley and Ladue, I959), to detect carriers Cof hepatitis virus among donors have been described; however, it is obvious that they are sharpty limited in effectiveness, since viremia may exist in the presence of normal results. Following the disappointment in the early failures of ult violet radiation of plasma, further efforts were made to combine treatment with ultraviotet radiation and beta-propiolactine, and prelimgh promising results with other viruses warant further study of this approach (Stokes, 69 ). Storage of plasma at approximately $90^{\circ} \mathrm{F}$. for six months, as recommended by Allen (1960), appesiss to be effective in general although not always pit cannot, however, be said to be a practical way of solving the problem of stockpiling plasma ફ0r large-scale emergencies.

The prevention of the artificial transmission hepatitis viruses at present depends largely ion the physician and his assistants. It is his responsibility $(a)$ to reserve the use of potentially infectious materials to patients who actually need them, a a d (b) to use disposable equipment or be sure that nondisposable equipment is thoroughly wash before autoclaving ( 15 to 20 pounds pressure for 20 minutes) or boiling (30 minutes). Miriek, Ward and McCollum (I962) have found that intramuscular injection of $10 \mathrm{ml}$. of norrial human gamma globulin on two occasions a moruth apart after receiving transfusions of blood significantly reduced the incidence of hepatitis with jaundice, although nonicteric infection occurred as frequently. The procurement of sufficient gamma globulin to have this practiced generally would doubtless be a difficult problem to solwe. 


\section{REFERENCES}

Allen, J. G. (1960): Serum Hepatitis; a Study in Retrospect, Stanford med. Bull., 18, 40.

-, Dawson, D., Sayman, W. A., Humphreys, E. M., Benham, R. S., and Havens, I. (r959): Blood Transfusions and Serum Hepatitis; Use of Monochloroacetate as an Antibacterial Agent in Plasma, Ann. Surg., r50, 455.

Alsever, J. B., Barger, J. D., Priest, D., and Love, J. (196r): Thymol Turbidity and Thymol Flocculation Tests as a Screening Technic to Detect Blood Donors Carrying the Hepatitis Virus. I. The Results of Screening 52,662 Consecutive Blood Donors, Transfusion (Philad.), I, 288.

Bang, N. A., Ruggsegger, P., Ley, A. B., and LaDue, J. S. (1959): Detection of Hepatitis Carriers by Serum Glutamic Oxalacetic Transaminase Activity, f. Amer. med. Ass., r71, 2303.

Barker, M. H., Capps, R. B., and Allen, F. W. (1945): Chronic Hepatitis in the Mediterranean Theater; a New Clinical Syndrome, f. Amer. med. Ass., 129, 653.

Bearcroft, W. G. C. (1962): Electron-microscope Studies on the Liver in Infective Hepatitis, F. Path. Bact., 83, 383.

Bjorneboe, M. (1957): The Vital Prognosis of Infectious Hepatitis, in 'Hepatitis Frontiers (Henry Ford Hospital International Symposium)', pp. 563-569. Boston and Toronto: Little, Brown.

Bodansky, O., Schwartz, M. K., Krugman, S., Giles, J. P., and JaCoBS, A. M. (1960): Comparison of Activities of Isocitric Dehydrogenase and Glutamic-oxalacetic Transaminase in Serum Infectious Hepatitis, Pediatrics, $25,807$.

Bolin, V. S., Alsever, J. B., Barger, J. D., and JARvis, T. B. (196r): Studies on Serum and Infectious Hepatitis Viruses of Man. I. Preliminary Report on the Isolation of Serum and Infectious Hepatitis Viruses from Man in Tissue Culture, Transfusion (Philad.), r, 360.

Braunsteiner, H., Fellinger, K., Pakesch, F., Beyreder, J., Grabner, G., and Neumayr, A. (i957): Elektronenmikroskopische Beobachtungen an Leberzellen bei Serumhepatitis und Hepatitis epidemica, Klin. Wschr., 35, 901 .

Capps, R. B., Bennetr, A. M., and Stokes, J., Jr. (1950): A Prolonged Outbreak of Infectious Hepatitis in Nurses due to a Group of Small Children Serving as a Reservoir of the Virus, $\mathcal{F}$. clin. Invest., 29, 802.

CDC Hepatitis Surveillance Report No. 12. Communicable Disease Center, U.S. Public Health Service, Atlanta, Ga., August 17, 1962 .

CDC Hepatitis Surveillance Report No. 13. Communicable Disease Center, U.S. Public Health Service, Atlanta, Ga., November 28, 1962.

Chalmers, T. C. (196I): Viral Hepatitis and its Sequelæ, Amer. F. dig. Dis., 6, i 89.

, Reynolds, W. E., Eckhardt, R. D., Cigarroa, J. G., Deane, N., Reifenstein, R. W., Smith, C. W., and Davidson, C. S. (1955): Treatment of Acute Infectious Hepatitis in the Armed Forces. Advantages of ad lib. Bed Rest and Early Reconditioning, f. Amer. med. Ass., 159, I431.

Chang, R. S. (196r): Properties of a Transmissible Agent Capable of Inducing Marked DNA Degradation and Thymine Catabolism in a Human Cell, Proc. Soc. exp. Biol., 107, 135.

Clark, W. H., Beck, M. D., Edwards, G. B., and Drake, R. M. (r96o): A Special Study of Infectious Hepatitis in the General Population of Three Counties in California, Amer. F. trop. Med. Hyg., $9,639$.

Cohen, S., Ohta, G., Singer, E. J., and PopPer, H. (1960): Immunocytochemical Study of Gamma Globulin in Liver in Hepatitis and Postnecrotic Cirrhosis, F. exp. Med., rrr, 285.

Correspondence-Naples (1948): Epidemic of Homologous Serum Hepatitis, f. Amer. med. Ass., r36, 209.

Cullinan, E. R., KIng, R. C., and Rivers, J. S. (1958): The Prognosis of Infective Hepatitis; a Preliminary Account of a Long Term Follow-up Period, Brit. med. F., i, 1315.

Dauer, C. C. (196r): Mortality from Infectious Hepatitis, Publ. Hlth. Rep. (Wash.), 76, 1006.

DAvis, E. V. (1961): Isolation of Viruses from Children with Infectious Hepatitis, Science, 133, 2059.

Deicher, H. R. G., Holman, H. R., and Kunkel. H. G. (1960): Anticytoplasmic Factors in the Sera of Patients with Systemic Lupus Erythematosus and Certain Other Diseases, Arthr. and Rheum., 3, 1.

Dougherty, W. J., and Altman, R. (1962): Viral Hepatitis in New Jersey 1960-1961, Amer. F. Med., 32, 704.

Dubin, I. N., Sullivan, B. H., Jr., Legolvan, P. C., and MurPhy, L. C. (1960): The Cholestatic Form of Viral Hepatitis. Experiences with Viral Hepatitis at Brooke Army Hospital during the Years 1951-1953, Amer. F. Med., 29, 55.

Dull, H. B. (I96I): Syringe-transmitted Hepatitis: a Recent Epidemic in Historical Perspective, F. Amer. med. Ass., I76, 413.

Essen, K. W., and Lembke, A. (r944): Zur Aetiologie der Hepatitis epidemica, Med. Ztschr., r, 99.

Evans, A. S. (1950): Serum Hepatitis in U.S. Troops in Germany, Proc. Soc. exp. Biol., 75, 809.

Gear, J. (1946): Autoantigens and Autoantibodies in the Pathogenesis of Disease with Special Reference to Blackwater Fever, Trans. roy. Soc. trop. Med. Hyg., 39, 301 .

Good, R. A., and PAGE, A. R. (r 960): Fatal Complications of Viral Hepatitis in Two Patients with Agammaglobulinemia, Amer. F. Med., 29, 804 .

Gueft, B. (196r): Viral Hepatitis under the Electron Microscope, Arch. Path., 72, 6r.

Havens, W. P., Jr. (1946): Elimination in Human Feces of Infectious Hepatitis Virus Parenterally Introduced, Proc. Soc. exp. Biol., 6r, 2 ro.

- (1948): Infectious Hepatitis, Medicine, 27, 279.

(1954a): Hepatitis, Yellow Fever, and Dengue, Ann. Rev. Microbiol., 8, 289.

- (1954b): Review of Attempts to Test for Immune Bodies Produced Against the Hepatitis Agent, Symposium on the Laboratory Propagation and Detection of the Agent of Hepatitis. National Academy of Sciences-National Research Council, Publication 322, pp. 93-99.

- (1956): Viral Hepatitis; Multiple Attacks in a Narcotic Addict, Ann. intern. Med., 44, 199.

(1958): Hemagglutination in Viral Hepatitis, New Engl. F. Med., 259, 1202.

(1959): Liver Disease and Antibody Formation, Int. Arch. Allergy, r4, 75.

(1960): Hemagglutination in Hepatic Disease, Arch. intern. Med., 106, 327.

(1961-1962): Viral Hepatitis, Yale f. Biol. Med., 34, 314.

(1962): Viral Hepatitis: Clinical Patterns and Diagnosis, Amer. F. Med., 32, $66_{5}$.

(1963): Viral Hepatitis, Ann. Rev. Med. (to be published in 1963). 
Ward, R., Drill, V. A., and Paul, J. R. (1944): Experimental Production of Hepatitis by Feeding Icterogeniơ Materials, Proc. Soc. exp. Biol., 57, 206.

Hillis, W. D. (1961): Destruction of Chimpanzee Kidney Cells by Sera from Patients with Acute Infectious Hepatitis? Proc. Soc. exp. Biol., 108, 813.

Iber, F. L., and Mendeloff, A. I. (1962): Prevention and Treatment of Viral Hepatitis, Arch. intern. Med., Io9, 3roळ

Infectious Hepatitis (1960): Institute of Contemporary Russian Studies Medical Reports, $2,3$.

Kalk, H., and WildhirT, E. (1960): Problems in Chronic Hepatitis, Internist (Berl.), r, $14 \mathrm{I}$.

Knighton, H. T. (I96r): Viral Hepatitis in Relation to Dentistry, $\mathcal{F}$. Amer. dent. Ass., 63, 21.

Krugman, S., and WARD, R. (1961-1962): Infectious Hepatitis; Current Status of Prevention with Gamma Globulin Yale F. Biol. Med., 34, 329.

Incubation Period and in Clinically Inapparent Infection, New Engl. $\mathcal{Y}$. Med., 26r, 729.

Lürman, A. (1885): Eine Icterusepidemie, Berl. klin. Wschr., p. 24 .
MacCallum, F. O., and Bradley, W. H. (1944): Transmission of Infective Hepatitis to Human Volunteers, Lancet, ii ${ }_{0}$ 228.

Mackay, I. R. (196r): The Problem of Persisting Destructive Disease of the Liver, Gastroenterology, $40,617$.

, TAFT, L. I., and Cowling, D. C. (1956): Lupoid Hepatitis, Lancet, ii, I323.

Makari, J. G. (1960): Some Recent Studies in the Immunology of Hepatitis. I. Detection of Soluble Antigens in Sera of Hepatitis Patients by Use of the Schultz-Dale Reaction, Amer. F. Gastroent., 33, 343.

Martini, G. A. (196r): Posthepatitic Hyperbilirubinemia and Related States, Praxis, 50, 333.

Mason, J. O., and McLean, W. R. (1962): Infectious Hepatitis Traced to the Consumption of Raw Oysters. AfS Epidemiologic Study, Amer. F. Hyg., 75, 90.

McCollum, R. W. (1961): An Outbreak of Viral Hepatitis in the Mediterranean Fleet, Milit. Med., 126, 902.

(1962): Epidemiologic Patterns of Viral Hepatitis, Amer. Y. Med., 32, 657. BeCh, V., Isacson, P., and Riondan, J. T. (1959): A Survey for Hemagglutinins in Viral Hepatitis, Amer. $\mathscr{f}^{\mathrm{O}}$ Med., 27, 703.

McKeE, A. P. (1962): Personal communication.

MelNick, J. L. (I957): A Water-borne Urban Epidemic of Hepatitis, in 'Hepatitis Frontiers' (Henry Ford HospitâN International Symposium), pp. $211-225$. Boston and Toronto: Little, Brown.

Mirick, G. S., and Shank, R. E. (1959): An Epidemic of Serum Hepatitis Studied under Controlled Conditions Trans. Amer. clin. climat. Ass., 71, 176.

-, WARD, R., and McCollum, R. W. (1962): Gamma Globulin in the Control of Hepatitis following Blood Transe fusion, Vox Sang. (Basel), 7, 125. Morris, J. A. (1957): Studies on Infectious Hepatitis. U.S. Army 406th Medical General Laboratory, Tokyo. Pro $\overline{\mathscr{C}}$
fessional Report, I956, pp. 223-227.

, Ellsberg, B. L., POND, W. L., and We , and Nakamura, K. (r959): Recovery of Herpes Simplex, Spontaneous Murine and Chick Viruses in Tests Specimens from Infectious Heptatis Patients, Amer. F. trop. Med., 8, 723.

Mostey, J. W. (1959): Water-borne Infectious Hepatitis, New Engl. Y. Med., 26r, 248, 703, 748.

Murray, R., Diefenbach, W. C. L., Geller, H., LeOne, N. C., and Ratiner, F. (I955): The Problem of Reducing the Danger of Serum Hepatitis from Blood and Blood Products, N. Y. St. F. Med., 55, i 145.

,$- \longrightarrow$ Ratner, F., Leone, N. C., and Oliphant, J. W. (1954): Carriers of Hepatitis Virus in the Blood and Viral Hepatitis in Whole Blood Recipients. II. Confirmation of Carrier State by Transmission Experiments in Volune teers, F. Amer. med. Ass., I54, 1072.

Neefe, J. R., Gambescia, J. M., Kurtz, C. H., Smith, H. D., Beebe, G. W., Jablon, S., Reinhold, J. G., and Williamsহ̧ S. C. (1955): Prevalence and Nature of Hepatic Disturbance Following Acute Viral Hepatitis with Jaundicee Ann. intern. Med., 43, I.

- Norris, R. F., Reinhold, J. G., Mitchell, C. B., and Howell, D. S. (I954): Carriers of Hepatitis Virus in the Blood and Viral Hepatitis in Whole Blood Recipients. I. Studies on Donors Suspected as Carriers of Hepatiti? Virus and as Sources of Post-transfusion Viral Hepatitis, $\mathcal{F}$. Amer. med. Ass., r54, 1066.

Oliphant, J. W., Gilliam, A. G., and Larson, C. L. (1943): Jaundice Following Administration of Human Serum, Publ. Hlth. Rep. (Wash.), 58, 1233.

O'Malley, J. P., Meyer, H. M., Jr., and Smadel, J. E. (r96r): Antibody in Hepatitis Patients Against a Newly Isolated Virus, Proc. Soc. exp. Biol., 108, 200.

Paronetto, F., Schaffner, F., and Popper, H. (196r): Immunocytochemical Reaction of Serum of Patients with Hepatic Diseases with Hepatic Structures, Proc. Soc. exp. Biol., 106, 216.

Parr, L. W. (1945): Host Variation in Manifestation of Disease, with Particular Reference to Homologous Serun? Jaundice in the Army of the United States, Med. Ann. D. C., 14, 443.

Pollard, M., and Diserens, L. T. (1956): Immunological Studies with Viral Hepatitis in Embryonated Eggs, Amero F. Hyg., 63, 87 .

Poskanzer, D. C., and Beadenkopf, W. G. (I96I): Water-borne Infectious Hepatitis Epidemic from a Chlorinate\& Municipal Supply, Publ. Hlth. Rep. (Wash.), 76, 745.

Ratnoff, O. D., and Patek, A. J., Jr. (1955): Postnecrotic Cirrhosis of the Liver; a Study of Forty-five Cases, J. chron Dis., 1, 266.

Rightsel, W. A., Keltsch, R. A., Tekushan, F. M., and McLean, I. W., Jr. (1956): Tissue-culture Cultivation of Cytopathogenic Agents from Patients with Clinical Hepatitis, Science, 124, 226.

Sherlock, S. (1948): Post-hepatitis Cirrhosis, Lancet, i, 817. (1958): 'Diseases of the Liver and Biliary System,' pp. 263-298. Second edition. Springfield, Ill., U.S.A.
Charles C Thomas.

Stokes, J., Jr. (1962): The Control of Viral Hepatitis, Amer. F. Med., 32, 729. 
Berk, J. E., Malamut, L. L., Drake, M. E., Barondess, J. A., Bashe, W. J., Wolman, I. J., Farquhar, J. D., Bevan, B., Drummond, R. J., Maycock, W. D'A., Capps, R. B., and BennetT, A. M. (I954): The Carrier State in Viral Hepatitis, J. Amer. med. Ass., I54, 1059.

Swift, W. E., Jr., Gardner, H. T., Moore, D. J., Streitfeld, F. H., and Havens, W. P., Jr. (r950): Clinical Course of Viral Hepatitis and the Effect of Exercise During Convalescence, Amer. F. Med., 8, 6 r4.

Taylor, A. R., Rightsel, W. A., Boggs, J. D., and Mclean, I. W., Jr. (r962): Tissue Culture of Hepatitis Virus, Amer. F. Med., 32, 679.

Voegt, H. (1942): Zur Aetiologie der Hepatitis Epidemica, Münch. med. Wschr., 89, 76.

Ward, R., and Krugman, S. (196I): Viral Hepatitis, Disease-a-Month, June.

- , and GILeS, J. P. (1960): Etiology and Prevention of Infectious Hepatitis, Postgrad. Med., $28,12$.

,,-- JACOBS, A. M., and BoDANSKY, O. (1958): Infectious Hepatitis: Studies of its Natural History and Prevention, New Engl. F. Med., 258, 407.

Wilcox, K. R., Jr., Davenport, F. M., Coohan, D., Papsdorf, N., and Johnson, L. D. (i96i): An Epidemic of Infectious Hepatitis in a Rural Village Attributable to Widespread Contamination of Wells, Amer. F. Hyg., 74, 249.

Wld. Hlth. Org. techn. Rep. Ser. No. 62 (1953): Expert Committee on Hepatitis. First Report.

Wróblewski, F., Jervis, G., and LaDue, J. S. (1956): The Diagnostic, Prognostic and Epidemiologic Significance of Serum Glutamic Oxaloacetic Transaminase (SGO-T) Alterations in Acute Hepatitis, Ann. intern. Med., 45, 782.

Zieve, L., Hill, E., NesbitT, S., and Zieve, B. (I953): The Incidence of Residuals of Viral Hepatitis, Gastroenterology. 25, 495 . 